\title{
The Effect of Cash Flow on Share Price of the Jordanian Commercial Banks Listed in Amman Stock Exchange
}

\author{
Ibrahim Marwan Khanji ${ }^{1} \&$ Ahmad Zakaria Siam ${ }^{1}$ \\ ${ }^{1}$ Finance and Banking Department, Al Balqa Applied University, Jordan \\ Correspondence: David Wolf II, School of Management, Northern Canada University, Toronto, ON., M3A 2K7, \\ Canada. Tel: 1-613-947-3592. E-mail: davidwolf@gc.ca
}

Received: February 3, 2015

Accepted: February 18, 2015

Online Published: April 25, 2015

doi:10.5539/ijef.v7n5p109

URL: http://dx.doi.org/10.5539/ijef.v7n5p109

\begin{abstract}
This study aims at examining the effect of cash flow on share price of the Jordanian commercial banks listed in Amman stock exchange, through measuring the effect of operational, investing and financing cash flow, as individual or jointly on the share price of the Jordanian commercial banks.

In order to achieve the objectives of the study a sample of twelve Jordanian commercial banks were chosen through intentional sampling approach, out of fifteen banks which constitutes the total number of the Jordanian commercial banks. These participating banks meet the requirement of the study.For the sake of the study, the analytical approach along with other necessary statistical methods have been utilized. Annual reports to obtain financial statements for the purpose of statements analysis are used too.

Statistical analysis indicates several results such as:

There is limited effect of operative, investment and financing cash flows on share market value of the Jordanian commercial banks (study's sample responses on items 10,20,132). Consequently, more concern is needed in regard to cash flow behavior when conducting share price assessment.
\end{abstract}

Keywords: Amman stock exchange, financing cash flow, investment cash flow, Jordanian commercial banks, operation cash flow, share price

\section{Introduction}

Global banking and financial challenges have resulted in more problem and difficulties on commercial banks. With accelerating technological progress, and increased fierce competition have contributed to increased problems that banks suffer from already. Globalization wide spread and economic openness in accelerated fashion which resulted in one way or another on commercial banks to adopt new and renewable strategies and mechanisms in the determination of their share price within the framework of cash flow. Their impact appeared vividly on the share price of the commercial banks.

Thus, the effect of cash flow effect appeared clearly on share price and make decisions to make pricing methods and instruments be based on accurate standards. In regard to cash flow, it has significant role in determining the need for cash availability in the time of dividends distribution time, and its effect on share price in a way that warranty the interests of stakeholders. Thus, it is inevitable to find or to have a new method to manage affairs within determined rules and standards. For those reasons cash flows have become in various forms: operative, investing and financing. Management becomes more interested in cash flow components in determining commercial banks share price, planning profitable liquidity and financing. In order to secure cash flow management on the basis of accountability and transparency. Thus, cash flow affected financial sector's both parts: banks and money market in terms of competency and which consider survival's landmarks.

\subsection{Significance and the Objective of the Study}

The significance of this study Stems from its discussion of the Jordanian commercial banks listed in Amman stock exchange population Also, this study is significance for being one of the pioneer studies which examines the effect of cash flow: operational, investment and financing simultaneously, on the share price of the Jordanian commercial banks, and this what mainly distinguishes it from other previous studies.

This study aims at examining the effect of cash flow on the share price of the Jordanian commercial banks listed 
in Amman stock exchange through achieving the following objectives:

1) Examining the extent of operational cash flows effect on share price of the Jordanian commercial banks listed in Amman stock exchange.

2) Examining the extent of investment cash flow on share price of the Jordanian commercial banks listed in Amman stock exchange.

3) Examining the extent of financing cash flow on share price of the Jordanian commercial banks listed in Amman stock exchange.

4) Examining the extent of operational, investment and financing cash flow joint effect on share price of the Jordanian commercial banks listed in Amman stock exchange.

\subsection{The Problem of the Study}

This study seeks the revealing of the cash flow effect on the share price of the Jordanian commercial banks, through the answering of the following questions which reflects the problem of the study:

1) What is the extent of operational cash flow effect on share price of Jordanian commercial banks listed in Amman stock exchange

2) What is the extent of Investment cash flow effect on share price of Jordanian commercial banks listed in Amman stock exchange.

3) What is the extent of financing cash flow effect on share price of Jordanian commercial banks listed in Amman stock exchange.

4) What is the extent of operational, financing and financing effect collectively on share price of Jordanian commercial banks listed in Amman stock exchange.

\subsection{Theoretical Framework and Previous Studies}

Cash flow statement is considered to be one of the most important financial statements which helps the users of such statement to know the firm's financial position subjected to analysis. Furthermore, the importance of financial statement stems from being able to reveal the cash effect of all the establishment's activities during a certain financial period, along with showing the nature of this effect for forming cash flow entering or exiting the company. In addition, the division of these statements to cash flow within activities have a joint nature that helps in revealing strength and weak points in term of establishment's ability to fulfillits obligations, finance expansions and dividends whether for a short or long term (Barkiah, 2009).

Thus, this statement can be defined, as a statement which reveals the changes in cash values of firm's operational, investing and financial activities during a certain period of time (Durgham, 2008). sees the statement as, cash flow statement is characterized by a high degree of subjectivity because it takes into consideration collected revenues and actually paid in comparison with net income which can be controlled by firm's management through optional expenses increase or decrees (Kadoumi \& Kailani, 2006, p. 125).

The cash flow statement aims at showing the firm's received cash money and cash payments during the accountancy period. In addition, it aims at reporting information relevant to firm's investment and financing activities during a certain period. Also, cash flow statement shows the effect of operational, investment and financing activities on cash during a certain fiscal period (Moh'd, Shaker, \& Abdel Nasser, 2005).

Wild, Subramanian and Halsey (2003). See that cash flow statement as it shows cash effects of current operational processes, investing and financing operations during a limited period and the net increase or decrease of cash during that period, then how that cash was used during that period.

Aqel (2000) points out that cash flow statement plays two distinguished roles: historical analysis of firm's financial position which helps in showing the establishments strong and weak points and the firm's future financial estimation based on its previous performance.

It must be noted that cash flow statement is one of the important financial statements- as mentioned earlierbecause it provides accountancy appropriate accounting information need for decision making. In addition, to benefit from such information in the firm's activities assessment (Mansour, 2006).

Wild, Subramanian and Halsey (2003). Point out that the preparing of cash flow statement assistsinvestors creditors and other in cash analysis through providing appropriate information about cash receivables and payables during a fiscal period. Whereas, cash flow statement shows cash effects of current operational process, and investment and financing processes during fiscal period, also, net increase or decrease in cash during the 
period. Then, how to use that cash during the period.

Studies indicate the relationship between investment return and free cash flow and its effect on the market value per share of Kuwaiti industrial firms in securities market. Similarly, Holy's (2013) study shows that used financial statement belongs to ten companies during the period of 2005-2012. Results showed the presence of statistically significant effect of free cash flow on shares market value for Kuwaiti companies listed in Kuwaiti securities market. Also, it revealed the presence of statistically significant effect of stock and free cash flow returns on the market value of the Kuwaiti companies shares listed in the Kuwaiti securities market. Thus, it must be inevitable to maintain share price stability with development in order to secure dividends distribution. This coincides with Ruixue (2008) study when it was conducted through the comparison of cash flow performance and dividends so as to clarify share price's movement. Also it aims to investigate how to maintain the increase of share price increase and limit fluctuations. Consequently, cash flow statement function to provide statements that are not available in other financial statements such as budget and income statement. These results are concurrent with the study of Khadash and Abadi (2005) which aimed at determining the returns and cash flow relationship to share market price assessment of Jordanian share holding manufacturing companies which assures that cash flow values and financial ratio are of at most importance in the company's financial position assessment.

From the aforementioned, it has been clear that the cash flow importance in share price determining of the Jordanian commercial banks, operational, financing and investing cast flow, are used in good fashion whether in determining the needed funding volume and ideal liquidity, and may be will not affect negatively on dividends distribution as an indicator for cash flow volume and its educated determining despite from obstacles and difficulties that hinders absolute accuracy in determining the cash flow effect on the Jordanian commercial banks' share price, which is the subject of this study.

\subsection{Hypotheses of the Study}

Based upon the study's theoretical framework and previous studies, and in accordance with the objectives of the study, the development of hypotheses can be as follow:

H01- there is no statistically significant relationship between operational cash flow and share price of the Jordanian commercial banks listed in Amman stock exchange.

H02- there is no statistically significant relationship between investing cash flow and share price of the Jordanian commercial banks listed in Amman stock exchange.

H03- there is no statistically significant relationship between financing cash flow and share price of the Jordanian commercial banks listed in Amman stock exchange.

H04- there is no statistically significant relationship between cash flow jointly and share price of the Jordanian commercial banks listed in Amman stock exchange.

\subsection{The Study's Population}

The study's population consists of all Jordanian commercial banks listed in Amman stock Exchange in the years 2010-2013. They reached up to 15 banks according to Amman Securities Exchange reports.

Sample: consists of 12 Jordanian commercial banks that meet the following criteria:

1) Its stocks have been exchanged regularly during the study period 2010-2013.

2) Its stocks never subjected to exchange halt during the study period 2010-2013.

3) Its stock never been subject to merging nor liquidity during the study period 2010-2013

Banks names and other relevant details are listed in Table 1.

Table 1. Banks details

\begin{tabular}{lccl}
\hline Banks name & Market value per share & No. of share & Market value in JD \\
\hline Arab Bank & 7.10 & 569.600 .000 & 4049 \\
Housing bank & 9.10 & 252.000 .000 & 2293 \\
Al Ahli Bank & 1.32 & 175.000 .000 & 231 \\
Bank of Jordan & 2.60 & 155.100 .000 & 404 \\
Arab E. Bank & 1.09 & 110.000 .000 & 199 \\
Jordan-Kuwaiti bank & 4.00 & 100.000 .000 & 400 \\
\hline
\end{tabular}




\begin{tabular}{llll}
\hline Cairo Amman Bank & 2.87 & 125.000 .000 & 358 \\
Al Itihad Bank & 1.80 & 110.000 .000 & 198 \\
Jordanian commercial bank & 1.10 & 100.000 .000 & 110 \\
Investment bank & 1.22 & 100.000 .000 & 122 \\
Arab Investment bank & 1.90 & 150.000 .000 & 285 \\
Al Mal Bank & 1.60 & 181.500 .000 & 290 \\
\hline
\end{tabular}

Source : annual reports of bank exchange in Amman stock.

\section{Data Collection Methods}

In addition to extensive review of relevant books, research, and published studies in scientific Journals and magazines, this researcher used the analytical approach and statistical ways in order to achieve the objectives of this study. Furthermore, this study utilized the participating Jordanian commercial bank's annual financial reports in order to obtain financial data which is used for financial statement purposes for the years 2010-2013.

In order to test the study's hypotheses SPSS statistical analysis method through regression equation. Regression coefficient $B, R^{2}$ and $(p)$ value are computed through SPSS along with statistically significance (Sig) at $5 \%$.

\section{Data Analysis and Hypotheses Testing}

In order to test hypotheses Linear Regression coefficient is used via SPSS program. Also to examine the effect extent of cash flow as independent variables $(1,2,3,4 \ldots \mathrm{X})$ on share price as dependent variable (y). whereas linear regression equation determines the coefficient value which reveals the effect extent of the independent variable on the dependent variable $\mathrm{R}^{2}$.

1) Dependent variable which represents share price $(Y)$ also to examine whether there is independent variables' effect on dependent variable, or not.

2) Independent variables are:

a) Cash flow from operational processes (X1);

b) Cash flow from investment processes (X2);

c) Cash flow from financing operations (X3);

d) Cash flow from operational, investing and financing operations collectively (X4).

\subsection{Testing First Hypothesis}

H01: there is no statistically significant relationship between operational cash flow and share price of the Jordanian commercial banks listed in Amman stock exchange.

Regression coefficient between the two variables is computed. It showed that regression coefficient is $\mathrm{B}=0,61$ as it is shown in table 2 between the independent variable (market share price) and dependent variable (cash flow from operational processes).

Table 2. Results of regression coefficient between the independent variable $\mathrm{X} 1$ and dependent variable (Y)

\begin{tabular}{lll}
\hline & & un standardized coefficients \\
Model 1 & & B \\
\hline 1 & constant & 2,088 \\
& X1 & 0,61 \\
& Sig & 0,33 \\
& R2 & $18 \%$ \\
\hline
\end{tabular}

Table 2 shows the statistical analysis results of operational cash flow has affected slightly on the market share price.

Coefficient $(\mathrm{P}(\mathrm{sig})=0,33$ which indicates that there is no statistically significant relationship between cash flow from operational processes and the market share value at $\% 5$. $\mathrm{R}^{2}$. Which explains the change in the dependent variable (market share price) indicates reason of the change in the independent variable (cash flow from operation processes) and for other reasons rather than independent variables. This indicates that this mean that $(0,18)$ from changes of dependent variable is due to other factors this assures us to accept the first hypothesis that 
indicates: there is no statistically significant relationship between operational cash flow and share price of the Jordanian commercial banks listed in Amman stock exchange.

\section{Second hypothesis Testing:}

H02: there is no statistically significant relationship between investment cash flow and share price of the Jordanian commercial banks listed in Amman stock exchange.

For this purpose $R^{2}$ between two variable is computed $B=(0,98)$ as shown in table 3 between independent variable- market share price- and the dependent variable, cash flow from investment.

Table 3. Result of regression Equation between independent variable X2 and dependent variable X2 and dependent variable $(\mathrm{Y})$

\begin{tabular}{lll}
\hline & & un standardized coefficients \\
Model & & B \\
\hline 1 & Constant & 1.8 \\
& X2 & 0.98 \\
& Sig & 0.41 \\
& R2 & $23 \%$ \\
\hline
\end{tabular}

Table 3 shows that statistical analysis for investment cash flow has affected slightly on the market share price coefficient $[\mathrm{p}(\mathrm{sig})=0,41]$ that shows that there is no statistically significance between cash flow from investment and market share value at $\% 5 . \mathrm{R}^{2}$ coefficient explains the change in dependent variable (market share price) because of change in the independent variable (cash flow from investment) and for other than independent variable. Whereas $R^{2}=0,23$ between the two variables. This indicates that $(0,23)$ of change in the dependent variable is caused by the change in the independent variable 0,77 of changes in the dependent are caused by other reasons. This assures us to accept the second hypothesis which indicates: there is no statistically significant relationship between investment cash flow and share price of the Jordanian commercial banks listed in Amman stock Exchange

H03 - there is no statistically significant relationship between financing cash flow and share price of the Jordanian commercial banks listed in Amman stock exchange.

$\mathrm{R}^{2}$ between two variables is computed. $\mathrm{B}=1,53$ as it is shown in table 4 , between independent variable (Market share value) and dependent variable (cash flow from financing).

Table 4. $\mathrm{R}^{2}$ equation results between independent variable $\mathrm{X} 3$ and dependent variable (Y)

\begin{tabular}{lll}
\hline & & un standardized coefficients \\
Model & & B \\
\hline 1 & Constant & 2.49 \\
& X3 & 1.53 \\
& P (Sig) & 0.25 \\
& R2 & $11 \%$ \\
\hline
\end{tabular}

Table 4 shows that there is a slight effect of financing cash flow on the market share price.

Coefficient $[\mathrm{p}(\mathrm{sig})=0,25]$ indicates that there is no statistically significant relationship between cash flow from financing operation and the market share price at 5\% coefficient (Sig) which explains change in the dependent variable (market share price) because of the change In the independent variable (cash flow from financing) and for other reasons rather than the independent variable whereas $\mathrm{R}^{2}=0,11$ between the two variables which indicates that 0,11 from change in the dependent variable is caused by change in the independent variable $(0,89)$ of changes of dependent variable which are caused by other reasons. This is no statistically significant relationship between cash flow from financing and market share price of the Jordanian commercial bank listed in Amman stock Exchange.

\section{Hypothesis four testing:}

H04: there is no statistically significant relationship between cash flow jointly cash flow and share price of the Jordanian commercial banks listed in Amman stock exchange. 
$\mathrm{R}^{2}$ between two variables is computed $\mathrm{B}=0,165$ - as it is shown in table 5- between the independent variable (market share price) and the dependent variable (net cash flow).

Table 5. Results of $\mathrm{R}$ equation between independent variable $\mathrm{X} 4$ and dependent variable (Y)

\begin{tabular}{lll}
\hline & & un standardized coefficients \\
Model & & B \\
\hline 1 & Constant & 2.82 \\
& X4 & 0.165 \\
& P (Sig) & 0.29 \\
& R2 & $16 \%$ \\
\hline
\end{tabular}

Table 5 shows the results of statistical analysis for operational, investment and financing net cash flow which slightly affected share price of the Jordanian commercial banks. Moreover [p (Sig)-0,29] coefficient which shows there is no statistically significant relation among operational, investment and financing net cash flow collectively and market share value at \%5 (Sig) coefficient which explains change in the dependent variable. operational, investment and financing collectively net cash flow. And to other reasons rather than the independent variable. Whereas $\mathrm{R}^{2}=0,16$ between the two variable is caused by the change in the independent variable and 0,84 of changes in the dependent variable cause by other reasons. This assures us to accept the fourth hypothesis: there is no statistically significant relationship between operational, investment and financing collectively cash flow and share price of Jordanian commercial banks listed in Amman stock Exchange.

\section{The Results of the Study}

According to the theoretical framework, data analysis and hypotheses testing, the study reached the following results:

1) There is no statically significant relationship between operational, investment share price of the Jordanian commercial banks listed in Amman stock exchange.

2) To a certain degree, Jordanian commercial banks do not differ from shareholding companies in other sectors in regard to cash flow and its relationship with stock price.

3) The low percentage of those who use operational investment and financing cash flow, individually or jointly as an indicator to determine Jordanian commercial banks share price for investment purposes.

4) Financial awareness culture still insufficient in regard to the significance operational, investment and financing cash flow whether individually or jointly, as an financial analysis instrument and determining share price of the Jordanian commercial banks.

\section{Recommendations}

Based upon the aforementioned results, the study puts forward the following recommendations:

1) It is necessary to call for more review and interest in showing clearly the rote of operational, investment and financing cash flow whether individually or jointly to be as major indicator for investment decision making process, Liquidity planning and the need for financing.

2) Investors awareness along with all those dealing parties by the importance of operational, investment and financing cash flow whether individually or jointly, in providing those who deal with receivables and payables statements which reflect the financial position safety to determine the value of stock price.

3) Support work to deliver information to investors in timely fashion, have Jordanian commercial banks to abide by its financial statement disclosure according to current international standards

4) Continue work to conduct further studies in different periods of time in order to reveal the role of operational, investment and financing cash flow individually and Jointly in explaining price behavior of Jordan commercial banks listed in Amman Stock Exchange.

\section{References}

Aqel, M. (2000). International in Financial management and analysis (2nd ed.). Mustakbal publishers, Amman Jordan.

Barkiah, A. (2009). The importance of cash flow information on stock market value of Saudi share holding companies. King Abdel Aziz University, Jeddah, KSA. 
Durgham, S. A. (2008). Relationship between cash flow and dividends according to the international accounting. No.7 unpublished Master's thesis, Gaza Islamic University.

Foroughi, D., Hadi, A., \& Manouchehr, M. (2011). Lack of transparency of financial information on the risk of future falls in the share prices of listed companies in Tehran Stock Exchange. Journal of Financial Accounting, 4(10), 15-40.

Hashemi, A., Samadi, S., \& YarSoroush, A. (2010). Evaluation of potential cash and accrual earnings components in forecasting abnormal earnings and valuation of listed companies in Tehran Stock Exchange. Financial Accounting Research, 1, 112-193.

Holy, F. A. (2013). Relationship between stock returns and free cash flow and their effect on share's market value. Amman Arab University, Amman.

Hossein, J., Zeinolabedin, S., \& Seyed, A. A. (2013). Cash Flow, Earning Opacity and its Impact on Stock Price Crash Risk in Tehran Stock Exchange. International Journal of Academic Research in Accounting, Finance and Management Sciences ,3(4), 138-145.

Kadoumi, T., \& Kailani, Q. (2006). The use of cash flow statement to evaluate the Jordanian shareholding Industrial Companies performance. Jordanian Applied Science Journal, 9(12).

Khadash, H., \& Al Abadi, M. I. (2005). Relationship of accountancy return and cash flow on shareholders rights in the market value per share. Management Science Journal, 32(1), 141-153.

Khodadi, \& Janjani. (2010). The reaction of investors to forecast earnings, cash flows and accruals enhancing Tehran Stock Exchange. Quarterly Stock Exchange, 8159-133.

Mansour, M. (2001). The extent of cash flow information on decision making process. Scientific Journal for Research and Commercial Studies, 1.

Mch'd, M., Shaker, I., \& Abdel Nasser, N. (2005). Financial analysis, Introduction to decision making. Amman Jordan: Wa'el publishers.

Ruixue, D. (2008). The Relationship Between Share Price and Operating Cash flow Under the Casual theme Restaurant Setting. MSC, and State University.

Wild, J. J., Subramanian, K. R., \& Halsey, R. F. (2003). Financial Statement Analysis (8th ed.). New York: McGraw, Hill Companies, Inc.

\section{Copyrights}

Copyright for this article is retained by the author(s), with first publication rights granted to the journal.

This is an open-access article distributed under the terms and conditions of the Creative Commons Attribution license (http://creativecommons.org/licenses/by/3.0/). 